\title{
Bucharest, Capital of Automatism: The 1940s Surrealist Group Iulian Toma
}

The surrealist group that was active in Bucharest in the mid-1940s occupies an important and increasingly recognized place in the context of international surrealism. Its members, who made their literary debuts in the interwar era, came to the fore in the Romanian capital in the immediate post-war years (1945-1947) following a period of clandestine activity during the war, with individual and collective publications (the latter primarily in French) ${ }^{1}$ and several exhibitions. The Bucharest group started to be acknowledged in the West early on. ${ }^{2}$ But it is since the 1980s, and in particular over the last two decades, that many studies devoted in whole or in part to this group (sometimes referred to by a key term recurrent in their work, the "infra-noir" 3 ) have definitively confirmed the major contribution of its literary, visual and theoretical works to the movement's heritage. Be they

1 The three collective works signed by the entire group are: L'Infra-noir: Préliminaires à une intervention sur thaumaturgique dans la conquète du désirable (1946), Éloge de Malombra: Cerne de l'amour absolu (1947), and "Le Sable nocturne" (1947). In addition, all but Gellu Naum, who resisted the turn to French, contributed two individual plaquettes to the 1947 "[Collection surréaliste] Infra-noir" series.

2 It figured in the Paris 1947 international surrealist exhibition with a collective text, "Le Sable nocturne" (see note 12), as well as in Jean-Louis Bédouin's 1959 historical account of the movement, Vingt ans de surréalisme 110-12.

3 For an analysis of the meaning of this term, which figures prominently in the title of the collective text accompanying the group's 1946 exhibition, see Eburne. As early as 1993, Sylvester and Whitfield use the term "Romanian surrealist group Infra-noir" (139) (cited in Yaari, "Groupe surréaliste de Bucarest"). Yaari eventually adopted this term as the denomination of the group. 
overview essays, ${ }^{4}$ monographic studies, ${ }^{5}$ collective publications,${ }^{6}$ or anthologies, ${ }^{7}$ the studies aimed at an international, mostly so far French-speaking readership, continue to proliferate. ${ }^{8}$ They are complemented by numerous analytical articles dealing with specific issues relating to collective or individual works of the group's members (Gherasim Luca, Gellu Naum, Paul Păun, Virgil Teodorescu, and Trost) and, increasingly, by translations of primary sources into English. ${ }^{9}$

We now know that the surrealist activities in Bucharest were characterized principally by frenzy, by an intensity of theory, and by the aspiration to revolutionize surrealism's artistic techniques and poetic language. As early as 1974, moreover, Sarane Alexandrian's study Le Surréalisme et le rêve asserted that the Bucharest surrealists had formed what was "le groupe le plus exubérant, le plus aventureux et même le plus délirant du surréalisme international" (221) 'the most exuberant, most adventurous and even most delirious group within international surrealism.' The five members of the group investigated the majority of the core questions of surrealist thought: love, objective chance, automatic writing, dream, the object, games, collage, and so on. Intimately acquainted with the history of the surrealist movement, the five group members strove to rethink its ideas and practices in permanent dialogue with psychoanalysis, Marxist thought, and the occult sciences. During the two years immediately after the war they feverishly generated leaflets, manifestos, exhibitions, collective experiments, and exchanges with their comrades in Paris and elsewhere. ${ }^{10}$ It is as if they were

4 Pop, "Repères pour une histoire du surréalisme roumain"; Vanci-Perahim, "Surréalisme en Roumanie"; Fauchereau, "Surréalisme en Roumanie"; Yaari, "Groupe surréaliste de Bucarest" and "Surrealist Group of Bucharest." See also entries on each of the group's members in Biro and Passeron, Dictionnaire général du surréalisme et de ses environs.

5 Laville on Gellu Naum; Carlat, Răileanu, Toma, and Torlini on Gherasim Luca.

6 Răileanu, L'Avant-garde roumaine; Le Surréalisme roumain, and, most recently, Yaari, "InfraNoir", un et multiple, the first book focused strictly on this group, bringing together scholars from three continents writing on both the literary and the graphic work of the group. See also the exhibition catalog La Planète affolée.

7 Pop, La Réhabilitation du rêve.

8 Editors' note: The bibliography in this article, although extensive, does not claim to be exhaustive. Aiming to document the critical reception of the group in the West, it does not include studies written in Romanian, which are of course numerous. Many complementary Romanian titles are included in the general bibliography to this volume.

9 In particular, translated books by Gherasim Luca as well as texts included in Richardson and Fijałkowski, Surrealism Against the Current.

10 1947, the year of the intensification of communist censorship, would cut short the explosion of surrealism in Romania, in a way that meant that the group was obliged to disband. In Paris, Gherasim Luca became "surrealist in non-surrealism" as he embarked on a personal poetic research he named ontophonie. For many years Gellu Naum only wrote 
living under the imperative to make up for lost time and to fix themselves on an even keel within the sphere of international surrealism. The clearest expression of this need is the announcement that opens the 1945 manifesto, Dialectique de la dialectique ("Dialectics of the Dialectic"), conceived by Gherasim Luca and Trost as a message "adressé au mouvement surréaliste international": "Nous nous adressons à nos amis surréalistes, dispersés dans le monde entier et comme dans les grands naufrages, nous leur indiquons notre position exacte, à $44^{\circ} 5^{\prime}$ de latitude nord, et $26^{\circ}$ de longitude est" (5) 'addressed to the international surrealist movement': 'This appeal is made to our surrealist friends, dispersed throughout the world, and as with major shipwrecks we signal our precise position, at $44^{\circ} 5^{\prime}$ latitude North, and $26^{\circ}$ longitude East' ("Dialectics" 32). By themselves or through the intermediary of their Parisian friends (Victor Brauner, Jacques Hérold, and Nadine Kraïnik), the members of the Bucharest surrealist group managed to establish correspondence and share their French language work with André Breton, Sarane Alexandrian, Georges Henein, René Magritte, the Czech surrealists, the London surrealists, and others, one of the reasons for this linguistic choice on their part, with the exception of Naum, being, as Monique Yaari also shows, the possibility of keeping alive "those passionate friendships and intellectual exchanges with far-away friends from the past and from a potential future" ("Surrealist Group of Bucharest" 101). Here we realize the full significance of the cry for freedom uttered by Gherasim Luca when, having managed to emigrate to Israel with Trost on their way to France, he communicated the news to Brauner: "Nous voilà sortis du monde de la suffocation" (Brauner 215) 'Here we are, finally out of the world of suffocation.' The word "suffocation" also expresses the feeling experienced by the poet faced with the oppression of censorship that had taken hold in Romania under the communist regime soon after the war.

One of the principal areas of animation in the activities of the Bucharest group during the 1940s, which spawned a good number of texts, experiments, games, and literary and visual endeavors, was born of the efforts of Gherasim Luca, Trost, and Paul Păun in particular to rethink the foundations of automatism. Of course, they affirmed, this process allows the exploration of the deep levels of consciousness, but its action should in no way be limited to the domain of subjectivity. One of the first critical positions taken against the non-dialectical nature of automatism was that of Gherasim Luca: "Je proposerais de trouver un nouveau langage.... Dans ce langage que je suis incapable de trouver, les anciennes antinomies ... sont résolues à une échelle, pour l'instant, individuelle"

surrealist poems in secret, while Virgil Teodorescu left the spirit of the movement behind. Settling in Israel in 1961, Paul Păun (now known as Paul Paon) maintained a strict discretion: the one book he wrote after his departure from Romania (La Rose parallèle, 1975) appeared in a limited and non-commercial edition (and is only now being prepared for republication). As for Trost, his surrealist trajectory came to an end in 1955 when his book Librement mécanique was published in Paris to negligible response. The graphic activity of Gherasim Luca and Paul Paon continued, but is only of late coming to the fore. 
(Vampire passif 47) 'I would propose the discovery of a new language. . . In this language, the one that I have been unable to find, the ancient antinomies ... will be resolved for the meanwhile at an individual level' (Passive Vampire 78-81). The criticism addressed towards surrealism here is of not having found the linguistic resources capable of expressing the depths of collective thought or of conveying individual revelations at the level of collective networks. In other words, if a superior reality, a surreality, does exist, then its manifestations should also be perceivable at the trans-individual level. It is true that these manifestations sometimes take the form of objective chance - correspondences between interior and exterior reality - but for the Bucharest surrealists these moments of contiguity proved to be far too rare and above all beyond their control. This observation was the start of their endeavor to imagine a means or a language that might better allow the harnessing or even the provocation of these correspondences. This reflection gave rise to the concept of surautomatisme, which precisely designated a method of knowledge facilitating the meeting of subjectivity and chance. It was Păun in particular who deployed and tried to define surautomatism:

L'automatisme, déjà disposé, déjà réceptif à toute influence extérieure propice, ne peut plus être désormais séparé du hasard objectif. . . . Car, pour le sur-automatisme, il n'y a plus d'obstacle réel s'opposant ... à la rencontre et à l'union du hasard et du désir. (Conspiration du silence 5)

Henceforth automatism, already open, already receptive to any favorable external influence, can no longer be separated from objective chance.... For, with sur-automatism, no real obstacle can exist that is opposed . . . to the meeting and the union of chance and desire.

Il faut envisager l'automatisme non comme une sonde de la subjectivité latente, mais comme une flèche ardente et spirale, éminemment objectivante. . . Le surautomatisme . . . en ouvrant aveuglément la porte du hasard, ... a largement démontré la complicité mystérieuse de toute la révolution concrète de l'univers.... (Esprits animaux 5)

We must conceive of automatism not as a probing of latent subjectivity, but as an ardent and spiriform arrow, one that is eminently objectivizing. ... Surautomatism ... , by blindly opening the door of chance, ... has broadly demonstrated the mysterious complicity of the whole of the concrete revolution of the universe....

The distinction Păun establishes between automatism as a probing that passively examines interiority and surautomatism imagined in the form of an arrow passing through the objective world reappears in the unpublished manifesto Déclaration sur la portée exacte de l'outrance poétique (Declaration on the Precise Scope of Poetic Excess) (again in 1947, per Doucet) authored by Luca, Păun, and Trost: 
L'automatisme, notre premier saut inaltérable, glacé à l'état de son premier jet, il nous appartient d'en faire éclater la trajectoire, en commençant par son passage de l'interne à l'externe, de la sonde à la flèche, de l'investigation à l'instigation, de la pensée à l'action. . . . Nous mettons à la base de toute efficacité les échanges réciproques de l'action automatique et du hasard effréné.

Automatism, our first immutable leap, frozen in the state of its first eruption, it is our task to burst open its trajectory, beginning with its path from the internal to the external, from the probe to the arrow, from investigation to instigation, from thought to action. ... We situate the reciprocal exchanges between automatic action and wild chance at the basis of all effectiveness.

But there is a second aspect to the criticism of automatism waged by the Bucharest surrealists, who warn against the 'impure' elements (diurnal remnants or Edipal traces) that might distort it when put into practice. Thus Trost repeatedly exposes the action of diurnal remnants:

Lorsque nous écrivons à l'aide de la méthode automatique ..., il n'est pas rare que certaines images parasitaires, quelques souvenirs désagréables, quelques noms repoussants apparaissent tout à coup. Ces interventions de la réalité sociale ne peuvent sûrement pas exprimer le fonctionnement réel de la pensée. ... (Vision dans le cristal 37)

When we write using the automatic method ..., it is not rare for certain parasitical images, some disagreeable memories, some repellent names suddenly to appear. These interventions of social reality surely cannot express the real functioning of thought....

En vérité, dans l'écriture automatique, à l'insu de l'auteur, certaines phrases toutes faites, certaines associations d'idées ou certaines interventions conscientes mécaniques interrompent parfois le développement réel de la pensée. Ces traces mnésiques ... sont rendues actives par l'existence des mots qui leur servent de support, en les véhiculant. (Profil navigable 31-32)

With automatic writing, in truth certain ready-made phrases, certain associations of ideas or conscious mechanical interventions sometimes interrupt the real development of thought without the author's knowledge. In conveying them, these mnemonic traces ... are made active by the words that act as their support.

In turn, Gherasim Luca questioned the principle of the unconscious associations on which automatism is based, by drawing attention to the fact that the Edipal determinations of the psyche are also reflected in automatic productions. This observation led him into a quest for a discursive paradigm in 
which individual units of meaning lose their CEdipal investment. Thus, in order to break this causal chain, Gherasim Luca turned to the materiality of language, towards the signifier, which he understood to be a receptacle for objective presence in the world. He was convinced that the linking together of words according to the principle of homophony, in other words through the intervention of chance, acquires a character that is in a way objective, with the subject no longer being entirely responsible for what it produces.

But the principle of surautomatism left its mark above all on the visual experiments and collective practices of the Bucharest surrealists. We can cite first of all Gherasim Luca's cubomanias, collages obtained using a process consisting of cutting a given image in a regular way into square fragments and sticking these pieces together at random. The images obtained, says Luca, will be those "de vos désirs" (Présentation) 'of your desires.' The mechanical intervention of chance as vector of automatism is also at the heart of several processes invented by Trost, which he named "surautomatisme des lignes et des surfaces" 'surautomatism of lines and surfaces,' "mouvements hypnagogiques" 'hypnagogic movements,' "mancies indéchiffrables" 'indecipherable clairvoyance,' "vaporisations" 'vaporizations' or "graphomanies entoptiques" 'entopic graphomanias.' In Păun's graphic work, the function of chance is rather that of triggering or stimulating the unconscious flux that "directs" the hand. This process is most clearly articulated in the definition of what he called lovaj, ${ }^{11}$ but is also at work in his abstract automatic drawings.

To these we can add the collective written productions of the entire group, such as the one titled L'Amour invisible (Invisible Love) (1946, per Doucet), "texte automatique collectif joué à Bucarest dans la nuit du nouvel an" (Gherasim Luca, "Liste") 'a collective automatic text played in Bucharest on the evening of New Year's Eve.' Although we are not provided with any details of the methodology employed or the contribution of each participant, this narrative-descriptive drama script project invites the reader to see it as a place of convergence of multiple subjectivities in which chance is responsible for harmonizing each of them in the objective presence of the others. We should also mention the sixteen 'descriptions' of objects on the occasion of the game known as "Sable nocturne" 'Nocturnal Sand" consisting, according to Sarane Alexandrian's recounting, "à entrer dans une chambre obscure, où avaient été disséminés des objets, et après avoir mis la main à tâtons sur l'un d'eux, à le décrire en état de surautomatisme" (669) 'of entering into a darkened room in which objects had been scattered, and after having felt

11 "Mets trois images sur une feuille blanche et établis entre elles la première relation formelle qui s'impose"'Place three images on a white sheet of paper and establish among them the first formal relation that imposes itself' (qtd. in Yaari, "Paul Paon ou le 'hurlesilence' 188). 
around for one of them with one's hand, of describing it in a state of surautomatism.' 12

It cannot be denied that the aspiration to define a mode of thought that reveals the indissociable character of automatism and objective chance constitutes one of the major vectors of the thought and activities of the Bucharest surrealists. There is no need to stress the flamboyant and daring nature of this undertaking, for after all it consists of nothing less than rethinking two of surrealism's "sacrosanct" concepts. But perhaps between the still painful memory of a war that had only just ended and the imminent totalitarian surge, the crucible of these alchemists of thought that were the Bucharest surrealists could only work at particularly high temperatures.

\section{Translated from the French by Krzysztof Fijalkowski}

\section{Works Cited}

Alexandrian, Sarane. Le Surréalisme et le rêve. Paris: Gallimard, 1974. Print.

L'Amour invisible. Signed by Gherasim Luca, Gellu Naum, Paul Păun, Virgil Teodorescu, and Trost. MS. GHL ms15. Bibliothèque littéraire Jacques Doucet, Paris.

Bédouin, Jean-Louis. Vingt Ans de surréalisme, 1939-1959. Paris: Denoël, 1961. Print.

Biro, Adam, and René Passeron, eds. Dictionnaire général du surréalisme et de ses environs. Fribourg: Office du livre, 1982. Print.

Brauner, Victor. Victor Brauner, écrits et correspondances, 1938-1948: Les Archives de Victor Brauner au Musée national d'art moderne. Ed. Camille Morando and Sylvie Patry. Paris: Centre Pompidou, Institut national d'histoire de l'art, 2005. Print. Archives de la Bibliothèque Kandinsky.

Carlat, Dominique. Gherasim Luca l'intempestif. Paris: Corti, 1998. Print. Les Essais.

Duplessis, Yvonne. “Le Surréalisme en Roumanie.” TNPX. N.p., 2004. Web. 29 Jan. 2015.

$<$ http://www.tnpx.net/document/conference\%20yvonne\%20duplesss.pdf $>$.

Text of a lecture given at the Institut Français, Bucharest.

Eburne, Jonathan. " 'Comme une érosion unique': Les Provocations d'Infra-noir." Yaari, Monique, ed., "Infra-Noir" 33-45. Print.

Fauchereau, Serge. "Le Surréalisme en Roumanie." Caiete critice 280 (2011): 7480; 282 (2011): 74-79. Print.

12 "Le Sable nocturne" is also the text the group sent to the 1947 international surrealist exhibition in Paris, and that was published in the exhibition's catalogue. 
Gherasim Luca. Liste de titres datés. MS. GHL ms26. Bibliothèque littéraire Jacques Doucet, Paris.

- The Passive Vampire. Tr. Krzysztof Fijalkowski. Prague: Twisted Spoon P, 2008. Print.

- Le Vampire passif. Paris: José Corti, 2001. Print.

Gherasim Luca, et al. "Le Sable nocturne." 1947. 56-58. Facsim rpt. in Yaari, "Infra-Noir" 373-75. Print.

Gherasim Luca, Paul Păun, and Trost. Déclaration sur la portée exacte de l'outrance poétique. MS. GHL ms18. Bibliothèque littéraire Jacques Doucet, Paris.

Gherasim Luca and Trost. "Dialectics of the Dialectic." Surrealism Against the Current: Tracts and Declarations. Ed. and trans. Michael Richardson and Krzysztof Fijałkowski. London: Pluto P, 2001. 32-41. Print.

—. Dialectique de la dialectique: Message adressé au mouvement surréaliste international. 1945. Facsim rpt. inYaari, "Infra-Noir" 239-69. Print.

- Présentation de graphies colorées, de cubomanies et d'objets. 1945. Facsim rpt. in Yaari, "Infra-Noir" 270-84. Print.

Laville, Rémy. Gellu Naum: Poète roumain prisonnier au château des aveugles. Paris: Harmattan, 1994. Print.

Lecherbonnier, Bernard. "Le S.O.S. roumain: Un Radical Rappel à l'ordre." La Chair du verbe: Histoire et poétique des surréalismes de langue française. Paris: Publisud, 1992. 57-61. Print. Collection Littératures.

Păun, Paul. La Conspiration du silence. 1947. Facsim rpt. in Yaari, "Infra-Noir", un et multiple 326-33. Print.

- Les Esprits animaux. 1947. Facsim rpt. in Yaari, "Infra-Noir", un et multiple 318-25. Print.

—. La Rose parallèle. Haïfa, n.p., 1975. Print. (As Paul Paon Zaharia.)

La Planète affolée: Surréalisme, dispersion et influences, 1938-1947. Marseille: Musées de Marseille; Paris: Flammarion, 1986. Print.

Pop, Ion, ed. La Réhabilitation du rêve: Une Anthologie de l'avant-garde roumaine. Paris: Nadeau, 2006. Print.

Pop, Ion. "Repères pour une histoire du surréalisme roumain." Mélusine 11 (1990): 143-55. Print.

Răileanu, Petre, ed. L'Avant-garde roumaine. Spec. issue of Le Rameau d'or 3 (19952). Print.

Răileanu, Petre. Gherasim Luca. Paris: Oxus, 2004. Print. Les Roumains de Paris. Richardson, Michael, and Krzysztof Fijałkowski, eds. Surrealism Against the Current: Tracts and Declarations. London: Pluto P, 2001. Print.

Sarré, Jean-Luc. "En Roumanie." La Planète affolée: Surréalisme, dispersion et influences, 1938-1947. Marseille: Musées de Marseille; Paris: Flammarion, 1986. 256-58. Print.

Le Surréalisme roumain. Spec. issue of Seine et Danube 3 (2004). Print. 
Sylvester, David, and Sarah Whitfield. Oil Paintings and Objects 1831-1948. Antwerp: Menil Foundation; Fonds Mercator, 1993. Vol. 2 of René Magritte: Catalogue raisonné. Ed. David Sylvester. 6 vols. 1992-2011. Print.

Toma, Iulian. Gherasim Luca, ou, L'Intransigeante Passion d'être. Paris: Champion, 2012. Print. Poétiques et esthétiques XXe-XXIe siècle 9.

Torlini, Yannick. Ghérasim Luca, le poète de la voix: Ontologie et érotisme. Paris: Harmattan, 2011. Print. Approches littéraires.

Trost. Librement mécanique. [Paris]: n.p., 1955. Print. Vision dans le cristal: Oniromancie obsessionnelle. Bucharest: Éditions de l'Oubli, 1945. Print.

Vanci-Perahim, Marina. "Le Surréalisme en Roumanie: Un peu, beaucoup, passionnément." Opus international 123-24 (April-May 1991): 136-40. Print.

Yaari, Monique. "Le Groupe surréaliste de Bucarest entre Paris et Bruxelles, 1945-1947: Une Page d'histoire." Synergies Canada 3 (2011). Web. 6 Feb. 2015. <http://synergies.lib.uoguelph.ca/article/view/1468>.

Yaari, Monique, ed. "Infra-Noir", un et multiple: Un groupe surréaliste entre Bucarest et Paris, 1945-1947. Oxford: Peter Lang, 2014. Print.

Yaari, Monique. "Paul Paon ou le 'hurle-silence.'” Yaari, Monique, ed., "InfraNoir" 151-98. Print.

. "The Surrealist Group of Bucharest: Collective Works, 1945-1947." Paris-

Bucharest, Bucharest-Paris: Francophone Writers from Romania. Ed. Anne Quinney. Amsterdam: Rodopi, 2012. 95-136. Print.

Copyright (C) 2015 Iulian Toma 